\title{
Trace element concentrations in feathers from three seabird species breeding in the Timor Sea
}

Jennifer L. Lavers ${ }^{\mathrm{a},},{ }^{,}$Emma Humphreys-Williams ${ }^{\mathrm{b}}$, Nicholas J. Crameri ${ }^{\mathrm{a}}$, Alexander L. Bond ${ }^{\mathrm{c}}$

anstitute of Marine and Antarctic Science, University of Tasmania, 20 Castray Esplanade, Battery

Point, Tasmania 7004, Australia

${ }^{b}$ Imaging and Analysis Centre, Core Research Labs, The Natural History Museum, Cromwell Road, London, SW7 5BD, United Kingdom

'Bird Group, Department of Life Sciences, The Natural History Museum, Akeman Street, Tring, Hertfordshire HP23 6AP, United Kingdom

*Corresponding Author. E-mail address: Jennifer.Lavers@utas.com.au (J.L. Lavers)

\section{ABSTRACT}

Mobile marine predators, such as seabirds, are frequently used as broad samplers of contaminants that are widespread in the marine environment. The Timor Sea off remote Western Australia is a poorly studied, yet rapidly expanding area of offshore development. To provide much needed data on contamination in this region, we quantified trace element concentrations in breast feathers of three seabird species breeding on Bedout Island. While adult Masked Boobies Sula dactylatra exhibited some of the highest concentrations, values for all species were below toxicology thresholds for seabirds and were comparable to those reported in other closely related species. The low concentrations detected in the birds provides a valuable baseline and suggests the local marine environment around Bedout is in relatively good condition. However, careful monitoring is warranted in light increasing anthropogenic activity in this region.

Keywords: Brown booby; Heavy metals; Lesser frigatebird; Masked booby; Offshore development; Western Australia 
The introduction of pollution into the environment is a major feature of anthropogenic change to our planet (Khan, 2018). Some well-known pollutants, including some trace elements, also occur naturally as part of biogeochemical cycles and volcanism (Burger et al., 1994). However, the background concentrations of many trace elements are undergoing dramatic increases in the industrial age due in large part to fossil fuel extraction and combustion (Nriagu and Pacyna, 1988). For example, mercury $(\mathrm{Hg})$ in the atmosphere and oceans has increased three-fold from preindustrial times (Lamborg et al., 2014).

Trace elements are typically differentiated into two categories: essential elements required for important processes within organisms, and non-essential elements that are not required for any biological purpose and are therefore particularly toxic when they accumulate within organisms (Burger, 1993; Ceyca et al., 2016; Moura et al., 2018). Several trace elements are of particular concern due to the concentrations released into the environment, as well as the documented toxicological effects at relatively low concentrations. They include the essential elements copper $(\mathrm{Cu})$, chromium ( $\mathrm{Cr})$, nickel ( $\mathrm{Ni})$, selenium $(\mathrm{Se})$, tin $(\mathrm{Sn})$ and zinc $(\mathrm{Zn})$ along with non-essential elements including $\mathrm{Hg}$, arsenic (As), cadmium (Cd) and lead (Pb; Burger, 1993; Moura et al., 2018).

In the marine environment, three elements $(\mathrm{Hg}, \mathrm{Pb}$, and $\mathrm{Cd}$ ) have been extensively studied because they bioaccumulate and biomagnify in aquatic food webs (Burger, 1993). Exposure can harm species in a variety of ways, including impaired biological function of proteins, enzymes, and cell damage (Burger, 1993; Ceyca et al., 2016). These impacts are often demonstrated using marine birds as sentinels, or bioindicators, as apex predators can also provide information on broader ecosystem health (Borghesi et al., 2016; Durant et al., 2009). Seabirds are also widespread, and unlike fish or marine mammals, are more readily sampled given they spend substantial time out of the water (Burger, 1993). Seabirds also display relatively predictable overwintering and breeding behaviours, allowing repeat sampling of individuals over time (Burger and Gochfeld, 2004; Mallory et al., 2010).

Feathers are often the preferred sampling media in avian studies as collection is largely noninvasive compared to sampling blood or other tissues (Monteiro and Furness, 1997). Being keratinous structures, feathers are chemically and physically stable, resistant to heat and deterioration, and are therefore easily stored over time (Burger et al., 1994; de Assis Padilha et al., 2018; Monteiro and Furness, 1997). Many seabird species sequester trace elements within growing feathers and exhibit well defined relationships between feather concentration and prey items (Borghesi et al., 2016; de Assis Padilha et al., 2018; Dolci et al., 2017). Feathers can also be collected from museum specimens, providing long-term data sets to analyse changes in trace elements over time (Bond et al., 2015a; Monteiro and Furness, 1997; Vo et al., 2011).

Here we investigate trace element concentrations within the breast feathers of three seabird species from Bedout Island, Western Australia (19.578 $\mathrm{S}$, $119.094^{\circ} \mathrm{E}$; Fig. 1): Brown Boobies (Sula leucogaster), Masked Boobies (S. dactylatra) and Lesser Frigatebirds (Fregata ariel). Generally, low concentrations of dissolved trace elements have been detected in the coastal and estuarine waters off north west Australia, indicating the region is in near pristine condition (Mackey, 1984; Munksgaard and Parry, 2001). However the Bedout, Browse, Canning, and northern Carnarvon Basins adjacent to Bedout Island hold economical deposits of oil and gas and are all undergoing varying degrees of exploration and extraction (DMIRS, 2014; Lavers et al., 2014; Thompson et al., 2018). Therefore, there is an urgent need to assess pollution levels in the otherwise poorlydocumented seabirds breeding in this rapidly developing region. Thus, the aims of this study were to 1) establish baseline trace element concentrations in three seabird species breeding in the region, and 2) assess whether current trace element concentrations may adversely affect the health of these species. 
Adult boobies were captured by hand from their nest at night using a net, while juvenile frigatebirds (nearly ready to fledge) were captured by hand from their nest pedestals during daylight from 22-24 November 2016 and 8-10 November 2017 on Bedout Island. Bedout Island is a 31 ha uninhabited island with low vegetation located in a remote, sparsely populated region of the north west coast of Australia (Johnson et al., 2013; Munksgaard and Parry, 2001), and is listed as an Important Bird and Biodiversity Area (BirdLife International, 2019). Four breast feathers were obtained from each bird and stored in sterile polyethylene bags at $-20^{\circ} \mathrm{C}$ until analysis. Breast feathers were used as they are thought to be more representative of body metal burdens compared to flight feathers (Furness et al., 1986).

Feather preparation and analysis was completed at the Natural History Museum Core Research Laboratories using Inductively Coupled Plasma Mass Spectrometry (ICP-MS) across a range of trace elements. Two feathers from each individual were placed using ethanol cleaned plastic tweezers in separate clean $12 \mathrm{ml}$ plastic vials and washed by submersing feathers in Suprapur ${ }^{\circledast} 0.25 \mathrm{M} \mathrm{NaOH}$ solution for 15 minutes, followed by two rinses with deionised water, and then dried at $60^{\circ} \mathrm{C}$ for 48 hours. We used two feathers per individual to account for within-individual variability (Bond and Diamond, 2008), which gave sample weights between $9 \mathrm{mg}$ and $27 \mathrm{mg}$

Following decontamination, the feathers were digested in $15 \mathrm{~mL}$ PFA vials which had been precleaned using 2-3 repeated treatments of $8 \mathrm{M} \mathrm{HNO}_{3}$ at $120^{\circ} \mathrm{C}$ for a minimum of 48 hours.

Approximately $1 \mathrm{~mL}$ of Romil ${ }^{\circledR} 8 \mathrm{M} \mathrm{HNO}_{3}$ was added to each sample vial which was then placed on a hotplate at $70^{\circ} \mathrm{C}$. An additional $1.5 \mathrm{~mL}$ of $8 \mathrm{M} \mathrm{HNO}_{3}$ was added to each vial after 60 minutes. After 48 hours, the hotplate was cooled from $70^{\circ} \mathrm{C}$ to $50^{\circ} \mathrm{C}$. The sample vial caps were then removed and 1 $\mathrm{mL}$ of Suprapur ${ }^{\circledast} 9.7 \mathrm{M} \mathrm{H}_{2} \mathrm{O}_{2}$ was added to each vial. Following any reaction, each vial was recapped and left on the hotplate for a further 12 hours at $70^{\circ} \mathrm{C}$. Each solution was then transferred to a dedicated clean, sealed container, where deionised water was added to dilute the sample to a total volume of $15 \mathrm{~mL}$. For inductively coupled plasma mass spectrometry (ICP-MS) analysis, a $2 \mathrm{~mL}$ aliquot of each sample solution was added into clean $12 \mathrm{~mL}$ tubes, with a further $2 \mathrm{~mL}$ of deionised water.

The digests were analysed using ICP-MS to quantify trace metal concentrations (Table S1). ICP-MS analysis was conducted on an Agilent $7700 x$ using a power of $1550 \mathrm{~W}, 1.07 \mathrm{~mL} / \mathrm{min}$ nebuliser gas flow, and He mode ( $5 \mathrm{ml} / \mathrm{min}$, He 99.9995\% purity) for all elements to reduce molecular interferences. Total procedural blanks were analysed and gave no detectable concentrations above the limit of quantification and certified reference materials were run every 10-15 samples using two reference materials from the Institut National de Santé Publique du Québec (INSPQ QM-H-Q1818, and QM-H-Q1827) and one from the Institute for Reference Material and Measurements, Joint Research Centre, European Commission (ERM-DB001; Table S1) certified for concentrations of As, $\mathrm{Cd}, \mathrm{Cu}, \mathrm{Hg}, \mathrm{Pb}, \mathrm{Tl}$ and $\mathrm{V}$.

To place our results in a broader context, we collated information on feather trace element concentrations in other sulids and frigatebirds from the literature (Table 1). In cases where summary statistics were not displayed in tables or the text, they were estimated from the plots provided in each paper using WebPlotDigitizer (Rohatgi, 2019).

Some samples were below the level of quantification $(<\mathrm{LOQ})$, and therefore left-censored (Table 2; Helsel, 2012). Summary statistics were calculated using maximum likelihood estimation in cases where $<10$ samples were below the level of quantification $(\mathrm{V}, \mathrm{Hg})$, and regression on order statistics in the case of As, where 23/59 samples were below the level of quantification (Bond et al., 2015b; Helsel, 2012). This was done in the R package NADA (Lee, 2017). All analyses were conducted using $R$ (R Core Team, 2019). 
We compared feather elemental concentrations in adult Brown and Masked Boobies using general linear models, and log-transformed data when it did not meet the assumptions of normality (Levene, 1960). Differences were considered significant when $p<0.05$.

A summary of elemental concentrations is provided for each of the three seabird species in Table 2. There was a significant difference in concentrations of $\mathrm{V}, \mathrm{Cu}, \mathrm{As}$, and $\mathrm{Hg}$ among species, and in all cases, Lesser Frigatebirds had the lowest concentrations; Brown Boobies had higher $\mathrm{V}$ concentrations in feathers than Masked Boobies (Table 3). There was no difference in trace element concentrations among years except for $\mathrm{V}$, where feathers from 2017 had significantly higher concentrations.

Only one individual, an adult Masked Booby $(5.04 \mu \mathrm{g} / \mathrm{g})$, exceeded the lowest observed adverse effect level (LOAEL) for $\mathrm{Pb}(4.00 \mu \mathrm{g} / \mathrm{g}$; Burger, 1993; Burger and Gochfeld, 2000), however an adult Brown Booby $(3.28 \mu \mathrm{g} / \mathrm{g})$ also approached this threshold. None of the birds tested approached the hypothesized LOAEL of $5.00 \mu \mathrm{g} / \mathrm{g}$ and $2.00 \mu \mathrm{g} / \mathrm{g}$ for $\mathrm{Hg}$ and Cd in seabird feathers, respectively (Burger, 1993; Burger and Gochfeld, 2000).

The seabird community on Bedout Island provides a valuable opportunity to comprehensively sample the marine environment as the three species included in this study exhibit distinct foraging ecologies or seasonality while breeding at the same location. While adult Brown Boobies on Bedout Island exhibited some of the highest trace element concentrations of the three species considered in this study (Table 1), values were below toxicology thresholds for seabirds (Burger, 1993), and were comparable to those reported in other closely related species (Table 1). The data for juvenile Lesser Frigatebirds suggests spatial or temporal differences could be important, with notable differences in $\mathrm{Hg}$ concentrations across two locations in the Timor region (Bedout Island (mean): $0.22 \pm 0.17 \mu \mathrm{g} / \mathrm{g}$; Ashmore Reef (median): $4.50 \mu \mathrm{g} / \mathrm{g}$; Table 1). Juvenile birds' feathers also represent a shorter period over which $\mathrm{Hg}$ can accumulate (Monteiro and Furness, 2001), so their low concentrations compared to the two boobies is expected. Overall, the low concentration of elements in all three seabird species sampled (Tables 1 and 2) suggests the local marine environment around Bedout Island is in relatively good condition, particularly compared to other areas with more offshore development (Boersma, 1986; Fraser, 2014).

For tropical sulids, numerous populations have undergone periods of rapid decline (Feare, 1978; Schreiber, 2000). For example, only a few sulid colonies remain in Indonesia, the Philippines, the South China Sea, and Papua New Guinea (Cao et al., 2005; de Korte and Meltofte, 1997; de Korte and Silvius, 1994; Jensen, 2007). The Masked Booby is nationally extinct in the Philippines and likely Indonesia (Jensen, 2007) and Australian colonies have also experienced historical declines or extirpations (Nelson, 2005; Serventy, 1952). These declines have been primarily attributed to anthropogenic disturbance, but chemical and physical pollution is increasingly identified as an issue of concern (e.g., Gilmour et al., 2019; Grant et al., 2018). Increasingly, seabirds are facing multiple pressures which, alone, may have been tolerable, but together may have additive or multiplicative effects, further affecting populations (Dias et al., 2019; Wiese et al., 2004). On Bedout Island, low numbers of Masked Boobies recorded in recent years ( $<100$ breeding pairs; Kingsley et al., 2019) and reductions in other seabirds in Australia and globally (Croxall et al., 2012; Dias et al., 2019; Gorta et al., 2019) suggests ongoing monitoring of this region is warranted. Furthermore, genetic analysis of Bedout's tiny Masked Booby population (likely subspecies $S$. $d$. bedoutti) indicates it rarely exchanges genes with other colonies in the region, meaning it has limited capacity to cope with pressures and recover from perturbations through immigration (Kingsley et al., 2019).

Along the north coast of Western Australia, seabirds increasingly overlap with offshore development (Lavers et al., 2014) as this is one of the most rapidly expanding regions of petroleum extraction (AERA, 2018; USGS, 2012). Drilling commenced in the Bedout Sub-basin, immediately adjacent to the island, in 2018 (Thompson et al., 2018). Risk of contamination or other harm to 
seabirds as a result of petrochemical activities is not insignificant, with Western Australia experiencing at least 13 offshore spillage events during 1988-2009 (May, 1992; Watson et al., 2009). When exposed to petroleum, seabirds exhibit elevated concentrations of trace elements and other pollutants in their tissues (Moreno et al., 2011; Pérez et al., 2008). Species that are resident yearround in areas of high development are at increased risk of exposure to spillage events, including members of the Sulidae which typically remain within 250-500 km of the nest site throughout the year (Huyvaert and Anderson, 2004; Kohno and Yoda, 2011; Weimerskirch et al., 2008).

The results of this study provide much-needed baseline data on trace element contamination for seabirds breeding on Bedout Island. While this is an important outcome, these data unfortunately resemble the majority of ecological studies, which focus on a single stressors due to time or funding limitations (O'Brien et al., 2019). In reality, $>70 \%$ of seabird species face multiple threats that often occur simultaneously at-sea and on their breeding islands (Dias et al., 2019). Thus, it's increasingly important to consider cumulative impacts on seabird populations and their habitats if we are to ensure research outcomes have meaningful application to the real world.

\section{Acknowledgements}

Special thanks to Detached Cultural Foundation, Women Divers Hall of Fame Research Grant, and the Western Australian Department of Biodiversity, Conservation and Attractions (DBCA; Pilbara region), especially A. Whittington and J. King for financial and/or logistical support. All biological samples were collected under the approval of the University of Tasmania Animal Ethics Committee (permits: A13746 and A16141) and the DBCA (permits: 01-000125-2 and 01-000125-4). Field support was kindly provided by A. Fidler and M. Grant from Adrift Lab, as well as K. Lyons and J. Vermeulen. Comments from $\mathrm{X}$ anonymous reviewers improved earlier drafts.

\section{References}

AERA, 2018. Australian Energy Resources Assessment (AERA) report, Canberra.

BirdLife International, 2019. Important Bird Areas factsheet: Bedout Island. Downloaded from http://www.birdlife.org on 29/03/2019.

Boersma, P.D., 1986. Ingestion of petroleum by seabirds can serve as a monitor of water quality. Science 231, 373-376. Bond, A.L., Diamond, A.W., 2008. High within-individual variation in total mercury concentration in seabird feathers. Environ. Toxicol. Chem. 27, 2375-2377.

Bond, A.L., Hobson, K.A., Branfireun, B.A., 2015a. Rapidly increasing methyl mercury in endangered Ivory Gull (Pagophila eburnea) feathers over a 130 year record. Proceedings of the Royal Society of London B 282, 20150032.

Bond, A.L., Robertson, G.J., Lavers, J.L., Hobson, K.A., Ryan, P.C., 2015b. Trace element concentrations in harvested auks from Newfoundland: toxicological risk of a non-indigenous subsistence hunt. Ecotoxicology and Environmental Safety 115, 1-6.

Borghesi, F., Migani, F., Andreotti, A., Baccetti, N., Bianchi, N., Birke, M., Dinelli, E., 2016. Metals and trace elements in feathers: A geochemical approach to avoid misinterpretation of analytical responses. Sci. Total Environ. 544, 476-494. Burger, J., 1993. Metals in avian feathers: bioindicators of environmental pollution. Rev. Enviro.Tox. 5, 203-311. Burger, J., Gochfeld, M., 2000. Metal levels in feathers of 12 species of seabirds from Midway Atoll in the northern Pacific Ocean. Sci. Total Environ. 257, 37-52.

Burger, J., Gochfeld, M., 2004. Marine birds as sentinels of environmental pollution. EcoHealth 1, 263-274.

Burger, J., Schreiber, E.A.E., Gochfeld, M., 1992. Lead, cadmium, selenium and mercury in seabird feathers from the tropical mid-pacific. Environ. Toxicol. Chem. 11, 815-822.

Burger, J., Veitch, C.R., Gochfeld, M., 1994. Locational differences in metal concentrations in feathers of Australasian Gannet (Morus serrator) in New Zealand. Environ. Monit. Assess. 32, 47-57.

Burgos-Núñez, S., Navarro-Frómeta, A., Marrugo-Negrete, J., Enamorado-Montes, G., Urango-Cárdenas, I., 2017. Polycyclic aromatic hydrocarbons and heavy metals in the Cispata Bay, Colombia: A marine tropical ecosystem. Mar. Pollut. Bull. 120, 379-386.

Cao, L., Pang, Y.L., Liu, N.F., 2005. Status of the Red-footed Booby on the Xisha Archipelago, South China Sea. Waterbirds 28, 411-419.

Ceyca, J.P., Castillo-Guerrero, J.A., García-Hernández, J., Fernández, G., Betancourt-Lozano, M., 2016. Local and interannual variations in mercury and cadmium in eggs of eight seabird species of the Sinaloa coast, México. Environ. Toxicol. Chem. 35, 2330-2338.

Croxall, J.P., Butchart, S.H.M., Lascelles, B., Stattersfield, A.J.J., Sullivan, B.J.J., Symes, A., Taylor, P., 2012. Seabird conservation status, threats and priority actions: a global assessment. Bird Cons. Int. 22, 1-34. 
de Assis Padilha, J., da Cunha, L.S.T., de Castro, R.M., Malm, O., Dorneles, P.R., 2018. Exposure of Magnificent Frigatebird (Fregata magnificens) and Brown Booby (Sula leucogaster) to metals and selenium in Rio de Janeiro state (Brazil) coastal waters. Orbital: The Electronic Journal of Chemistry 10, 254-261.

de Korte, J., Meltofte, H., 1997. Notes on breeding sites of Pelecaniformes in Micronesia. Bird Cons. Int. 7, 287-290.

de Korte, J., Silvius, M.J., 1994. Pelecaniformes in Indonesia: status, recent changes and management, pp. 77-93.

Dias, M.P., Martin, R.E., Pearmain, E.J., Burfield, I.J., Small, C., Phillips, R.A., Yates, O., Lascelles, B., Borboroglu, P.G., Croxall, J.P., 2019. Threats to seabirds: A global assessment. Biol. Cons.

DMIRS, 2014. Western Australia's petroleum and geothermal explorer's guide - 2014 Edition. Western Australia Department of Mines and Petroleum, Perth, Western Australia.

Dolci, N.N., Sá, F., da Costa Machado, E., Krul, R., Rodrigues Neto, R., 2017. Trace elements in feathers and eggshells of Brown Booby Sula leucogaster in the marine national park of Currais Islands, Brazil. Environ. Monit. Assess. $189,496$. Durant, J.M., Hjermann, D., Frederiksen, M., Charrassin, J.B., Le Maho, Y., Sabarros, P.S., Crawford, R.J.M., Stenseth, N.C., 2009. Pros and cons of using seabirds as ecological indicators. Climate Research 39, 115-129.

Feare, C.J., 1978. The decline of booby populations in the western Indian Ocean. Biology Conservation 14.

Fraser, G., 2014. Impacts of offshore oil and gas development on marine wildlife resources, Peak oil, economic growth, and wildlife conservation. Springer, New York, NY, pp. 191-217.

Furness, R.W., Muirhead, S.J., Woodburn, M., 1986. Using bird feathers to measure mercury in the environment:

Relationships between mercury content and moult. Mar. Pollut. Bull. 17, 27-30.

Gilmour, M.E., Hudson, S.A.T., Lamborg, C., Fleishman, A.B., Young, H.S., Shaffer, S.A., 2019. Tropical seabirds sample broadscale patterns of marine contaminants. Sci. Total Environ. 691, 631-643.

Gorta, S.B.Z., Smith, J.A., Everett, J.D., Kingsford, R.T., Cornwell, W.K., Suthers, I.M., Epstein, H., McGovern, R., McLachlan, G., Roderick, M., Smith, L., Williams, D., Callaghan, C.T., 2019. Pelagic citizen science data reveal declines of seabirds off south-eastern Australia. Biol. Cons. 235, 226-235.

Grant, M.L., Lavers, J.L., Stuckenbrock, S., Sharp, B., Bond, A.L., 2018. The use of anthropogenic marine debris as a nesting material by Brown Boobies (Sula leucogaster). Mar. Pollut. Bull. 137, 96-103.

Helsel, D.R., 2012. Statistics for censored environmental data using Minitab and R, 2nd edition ed. John Wiley \& Sons, Inc, Hoboken, New Jersey.

Huyvaert, K.P., Anderson, D.J., 2004. Limited dispersal by Nazca Boobies Sula granti. J. Avian Biol. 35, 46-53.

Jensen, A., 2007. Conservation of seabirds and threatened avifauna in the Cagayan Ridge Marine Biodiversity Conservation Corridor, the Sulu Sea, Philippines, Manila, Philippines.

Johnson, R.E.B., Burbidge, A.H., Darnell, J.C., 2013. Birds of the Pilbara region, including seas and offshore islands, Western Australia: distribution, status and historical changes. Records of the Western Australian Museum Supplement 78, 343-441. Khan, F.R., 2018. Ecotoxicology in the Anthropocene: Are we listening to nature's scream? Environ. Sci. Technol. 52, 1022710229.

Kim, E.Y., Murakami, T., Saeki, K., Tatsukawa, R., 1996. Mercury levels and its chemical form in tissues and organs of seabirds. Arch. Environ. Contam. Toxicol. 30, 259-266.

Kingsley, M.R., Lavers, J.L., Steeves, T.E., Burridge, C.P., 2019. Genetic distinctiveness of Masked Booby (Sula dactylatra) on Bedout Island, Western Australia. Emu.

Kohno, H., Yoda, K.E.N., 2011. The development of activity ranges in juvenile Brown Boobies Sula leucogaster. Ibis 153, 611-615.

Lamborg, C.H., Hammerschmidt, C.R., Bowman, K.L., Swarr, G.J., Munson, K.M., Ohnemus, D.C., Lam, P.J., Heimburger, L.E., Rijkenberg, M.J.A., Saito, M.A., 2014. A global ocean inventory of anthropogenic mercury based on water column measurements. Nature 512, 65-68.

Lavers, J.L., Miller, M.G.R., Carter, M.J., Swann, G., Clarke, R.H., 2014. Predicting the spatial distribution of a seabird community to identify priority conservation areas in the Timor Sea. Cons. Biol. 28, 1699-1709.

Lee, L., 2017. NADA: Nondetects And Data Analysis for environmental data, R package version 1.6-1 ed.

Levene, H., 1960. Robust tests for equality of variances, in: Olkin, I. (Ed.), Contributions to probability and statistics: Essays in honor of Harold Hotelling. Stanford University Pres, Stanford, pp. 278-292.

Lock, J.W., Thompson, D.R., Furness, R.W., Bartle, J.A., 1992. Metal concentrations in seabirds of the New Zealand region. Environ. Pollut. 75, 289-300.

Mackey, D., 1984. Trace metals and the productivity of shelf waters off north west Australia. Mar. Freshwater Res. 35, 505516.

Mallory, M.L., Robinson, S.A., Hebert, C.E., Forbes, M.R., 2010. Seabirds as indicators of aquatic ecosystem conditions: A case for gathering multiple proxies of seabird health. Mar. Pollut. Bull. 60, 7-12.

May, R.F., 1992. Marine conservation reserves, petroleum exploration and development, and oil spills in coastal waters of Western Australia. Mar. Pollut. Bull. 25, 147-154.

Monteiro, L.R., Furness, R.W., 1997. Accelerated increase in mercury contamination in North Atlantic mesopelagic food chains as indicated by time series of seabird feathers. Environ. Toxicol. Chem. 16, 2489-2493.

Monteiro, L.R., Furness, R.W., 2001. Kinetics, dose-response, and excretion of methylmercury in free-living adult Cory's Shearwaters. Environ. Sci. Technol. 35, 739-746.

Moreno, R., Jover, L., Diez, C., Sanpera, C., 2011. Seabird feathers as monitors of the levels and persistence of heavy metal pollution after the Prestige oil spill. Environ. Pollut. 159, 2454-2460. 
Mott, R., Herrod, A., Clarke, R.H., 2017. Post-breeding dispersal of frigatebirds increases their exposure to mercury. Mar. Pollut. Bull. 119, 204-210.

Moura, J.F., Tavares, D.C., Lemos, L.S., Acevedo-Trejos, E., Saint'Pierre, T.D., Siciliano, S., Merico, A., 2018. Interspecific variation of essential and non-essential trace elements in sympatric seabirds. Environ. Pollut. 242, 470-479.

Munksgaard, N.C., Parry, D.L., 2001. Trace metals, arsenic and lead isotopes in dissolved and particulate phases of North Australian coastal and estuarine seawater. Mar. Chem. 75, 165-184.

Nelson, J.B., 2005. Pelicans, cormorants, and their relatives - The Pelecaniformes. Oxford University Press, Oxford. Nriagu, J.O., Pacyna, J.M., 1988. Quantitative assessment of worldwide contamination of air, water and soils by trace metals. Nature 333, 134-139.

O'Brien, A.L., Dafforn, K.A., Chariton, A.A., Johnston, E.L., Mayer-Pinto, M., 2019. After decades of stressor research in urban estuarine ecosystems the focus is still on single stressors: A systematic literature review and meta-analysis. Sci. Total Environ. 684, 753-764.

Pérez, C., Velando, A., Munilla, I., López-Alonso, M., Oro, D., 2008. Monitoring polycyclic aromatic hydrocarbon pollution in the marine environment after the Prestige oil spill by means of seabird blood analysis. Environ. Sci. Technol. 42, 707-713. $\mathrm{R}$ Core Team, 2019. R: a language and environment for statistical computing. Version 3.6.1 [computer program]. R Foundation for Statistical Computing, Vienna, Austria.

Rohatgi, A., 2019. WebPlotDigitizer version 4.2.

Schreiber, E.A., 2000. Status of Red-footed, Brown and Masked Boobies in the West Indies, in: Schreiber, E.A., Lee, D.S. (Eds.), Status and conservation of West Indian seabirds, pp. 46-57.

Serventy, D.L., 1952. The bird islands of the Sahul Shelf: with remarks on the nesting seasons of Western Australian seabirds. Emu 52, 33-59.

Thompson, M., Wehr, F., Woodward, J., Minken, J., D’Orazio, G., Fernandes, F., Kongowoin, M., Hansen, L., Kuek, D., Fabrici, R., 2018. Recent exploration results in the Lower Triassic, Bedout Sub-basin: Australia's next petroleum province? . APPEA Journal 58, 871-877.

USGS, 2012. Assessment of undiscovered conventional oil and gas resources of Bonaparte Basin, Browse Basin, Northwest Shelf, and Gippsland Basin provinces, Australia, 2011, in: Pollastro, R.M., Brownfield, M.E., Charpentier, R.R., Cook, T.A., Klett, T.R., Kirschbaum, M.A., Pitman, J.K., Schenk, C.J. (Eds.), World Petroleum Resources Project, Fact sheet 2012-3025. U.S. Department of the Interior, United States Geological Survey.

Vo, A.-T.E., Bank, M.S., Shine, J.P., Edwards, S.V., 2011. Temporal increase in organic mercury in an endangered pelagic seabird assessed by century-old museum specimens. Proc. Nat. Acad. Sci. 108, 7466-7471.

Watson, J.E.M., Joseph, L.N., Watson, A.W.T., 2009. A rapid assessment of the impacts of the Montara oil leak on birds, cetaceans and marine reptiles. Department of the Environment, Water, Heritage and the Arts, Canberra.

Weimerskirch, H., Le Corre, M., Bost, C.A., 2008. Foraging strategy of Masked Boobies from the largest colony in the world: relationship to environmental conditions and fisheries. Mar. Ecol. Prog. Ser. 362, 291-302.

Wiese, F.K., Robertson, G.J., Gaston, A.J., 2004. Impacts of chronic marine oil pollution and the murre hunt in Newfoundland on Thick-billed Murre Uria lomvia populations in the eastern Canadian Arctic. Biol. Cons. 116, 205-216. 

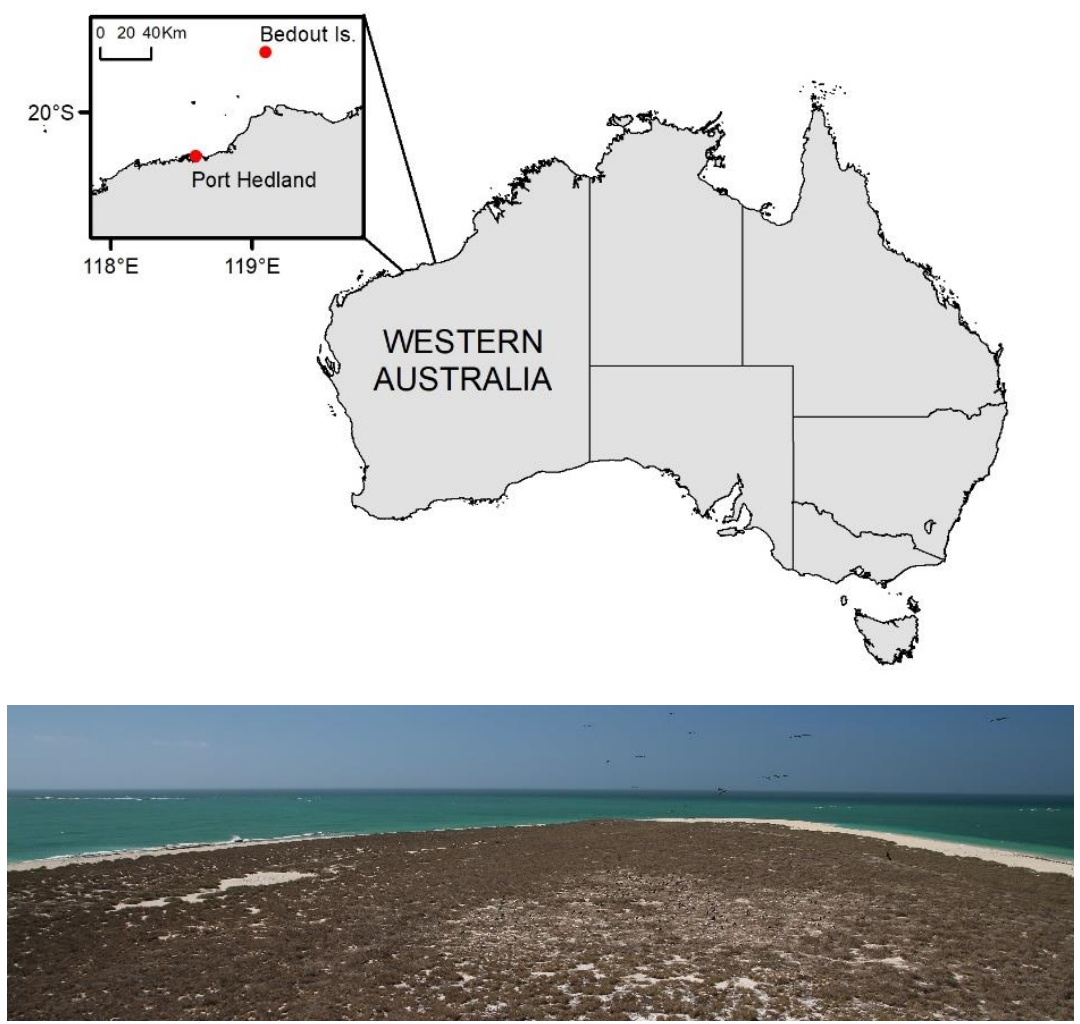

Fig. 1. Top panel: map showing the location of Bedout Island. Bottom panel: the Lesser Frigatebird colony (center of image; looking north) and the main Masked Booby colony (unvegetated area on left) on Bedout Island. Brown boobies breed along the shoreline, especially on the eastern side. 
Table 1

Trace element concentrations ( $\mu \mathrm{g} / \mathrm{g})$ in breast feathers of adult Sulidae and juvenile Fregatidae, reported as mean \pm SD. N/A = information not available.

\begin{tabular}{|c|c|c|c|c|c|c|c|c|c|c|c|c|c|c|c|}
\hline Species & Site & Year & $\begin{array}{l}\text { Sample } \\
\text { size }(n)\end{array}$ & $\mathrm{Hg}$ & $\mathrm{Cd}$ & $\mathrm{Pb}$ & $\mathrm{Se}$ & $\mathrm{Cu}$ & $\mathbf{v}$ & $\mathrm{Zn}$ & As & $\mathrm{Mn}$ & Sn & $\mathrm{Cr}$ & Source \\
\hline \multirow{7}{*}{$\begin{array}{l}\text { Sula } \\
\text { dactylatra } \\
\text { Sula } \\
\text { leucogaster }\end{array}$} & Bedout Is., & 2016- & 20 & $3.20 \pm$ & $0.03 \pm$ & $0.48 \pm$ & & $2.92 \pm$ & $0.02 \pm$ & & $0.01 \pm$ & & & & This study \\
\hline & Timor Sea & 2017 & & 0.62 & 0.03 & 0.36 & & 0.81 & 0.01 & & 0.01 & & & & \\
\hline & Bedout Is., & 2016- & 16 & $1.55 \pm$ & $0.04 \pm$ & $0.59 \pm$ & & $2.86 \pm$ & $0.04 \pm$ & & $0.01 \pm$ & & & & This study \\
\hline & Timor Sea & 2017 & & 0.89 & 0.07 & 0.36 & & 0.92 & 0.03 & & 0.01 & & & & \\
\hline & North Pacific & 1990 & 12 & $\begin{array}{l}1.90 \pm \\
0.33\end{array}$ & $\begin{array}{l}0.14 \pm \\
0.02\end{array}$ & $\begin{array}{l}2.33 \pm \\
0.30\end{array}$ & $\begin{array}{l}3.68 \pm \\
0.48\end{array}$ & & & & & & & & $\begin{array}{l}\text { Burger et al. } \\
\text { (1992) }\end{array}$ \\
\hline & Ryukyu Is., & 1992 & 11 & $2.9 \pm$ & & & & & & & & & & & Kim et al. \\
\hline & Japan & & & 1.0 & & & & & & & & & & & (1996) \\
\hline \multirow[t]{4}{*}{ Sula sula } & North Pacific & 1990 & 12 & $3.57 \pm$ & $0.13 \pm$ & $2.08 \pm$ & $2.28 \pm$ & & & & & & & & Burger et al. \\
\hline & & & & 0.28 & 0.03 & 0.32 & 0.34 & & & & & & & & (1992) \\
\hline & North Pacific & $\mathrm{N} / \mathrm{A}$ & 12 & $3.85 \pm$ & $0.05 \pm$ & $0.975 \pm$ & $2.34 \pm$ & & & & $0.12 \pm$ & $1.46 \pm$ & $2.28 \pm$ & $2.53 \pm$ & Burger and \\
\hline & & & & 0.09 & 0.01 & 0.04 & 0.05 & & & & 0.01 & 0.14 & 0.12 & 0.26 & $\begin{array}{l}\text { Gochfeld } \\
(2000)\end{array}$ \\
\hline \multirow{7}{*}{$\begin{array}{l}\text { Morus } \\
\text { serrator }\end{array}$} & Pakiri Beach, & N/A & 11 & $4.47 \pm$ & $0.09 \pm$ & $0.82 \pm$ & $1.03 \pm$ & & & & & $1.08 \pm$ & & $1.78 \pm$ & Burger et al. \\
\hline & New Zealand & & & 0.18 & 0.01 & 0.09 & 0.06 & & & & & 0.05 & & 0.05 & (1994) \\
\hline & Muriwai Beach, & $\mathrm{N} / \mathrm{A}$ & 12 & $3.89 \pm$ & $0.22 \pm$ & $3.13 \pm$ & $1.85 \pm$ & & & & & $2.65 \pm$ & & $3.43 \pm$ & \\
\hline & New Zealand & & & 0.21 & 0.02 & 0.28 & 0.09 & & & & & 0.18 & & 0.19 & \\
\hline & Ninety Beach, & $\mathrm{N} / \mathrm{A}$ & 21 & $3.8 \pm$ & $0.20 \pm$ & $1.13 \pm$ & $2.04 \pm$ & & & & & $3.98 \pm$ & & $6.25 \pm$ & \\
\hline & New Zealand & & & 0.10 & 0.01 & 0.08 & 0.04 & & & & & 0.13 & & 0.25 & \\
\hline & N/A & $\mathrm{N} / \mathrm{A}$ & 1 & 4.5 & & 0.9 & & 19.9 & & 102.0 & & & & & $\begin{array}{l}\text { Lock et al. } \\
\text { (1992) }\end{array}$ \\
\hline \multirow{3}{*}{ Fregata ariel } & Bedout Is., & 2016- & 23 & $0.22 \pm$ & $0.03 \pm$ & $0.82 \pm$ & & $1.32 \pm$ & $0.01 \pm$ & & $<0.01 \pm$ & & & & This study \\
\hline & Timor Sea & 2017 & & 0.17 & 0.02 & 1.26 & & 0.32 & 0.03 & & 0.01 & & & & \\
\hline & $\begin{array}{l}\text { Ashmore Reef, } \\
\text { Timor Sea }\end{array}$ & $\begin{array}{l}2013- \\
2014\end{array}$ & 38 & $4.41^{\mathrm{a}}$ & & & & & & & & & & & $\begin{array}{l}\text { Mott et al. } \\
(2017)\end{array}$ \\
\hline Fregata minor & $\begin{array}{l}\text { Ashmore Reef, } \\
\text { Timor Sea }\end{array}$ & $\begin{array}{l}2013- \\
2014\end{array}$ & 6 & $2.6^{\mathrm{a}}$ & & & & & & & & & & & $\begin{array}{l}\text { Mott et al. } \\
\text { (2017) }\end{array}$ \\
\hline $\begin{array}{l}\text { Fregata } \\
\text { magnificens }\end{array}$ & $\begin{array}{l}\text { Cispata Bay, } \\
\text { Colombia }\end{array}$ & $\begin{array}{l}2010- \\
2011\end{array}$ & 7 & $\begin{array}{l}2.10 \pm \\
1.36\end{array}$ & $\begin{array}{l}0.34 \pm \\
0.32\end{array}$ & $\begin{array}{l}0.19 \pm \\
0.09\end{array}$ & & $\begin{array}{l}3.65 \pm \\
4.99\end{array}$ & & $\begin{array}{l}61.64 \pm \\
42.39\end{array}$ & & & & & $\begin{array}{l}\text { Burgos-Núñez } \\
\text { et al. (2017) }\end{array}$ \\
\hline
\end{tabular}

${ }^{a}$ Median values extracted from plots (see Methods for details) 
Table 2

Trace element concentrations $(\mu \mathrm{g} / \mathrm{g})$ in seabird breast feathers from Bedout Island.

\begin{tabular}{|c|c|c|c|c|c|}
\hline Element & \#<LOQ & Min & Median & Max & Mean (SD) \\
\hline \multicolumn{6}{|c|}{ Brown Booby (Sula leucogaster) - adults } \\
\hline \multicolumn{6}{|c|}{$2016(n=11)$} \\
\hline V & 0 & 0.03 & 0.04 & 0.09 & $0.06(0.03)$ \\
\hline $\mathrm{Cu}$ & 0 & 2.27 & 2.56 & 5.94 & $2.93(1.03)$ \\
\hline As & $2(18 \%)$ & $<0.03$ & NA & 0.10 & NA \\
\hline $\mathrm{Cd}$ & 0 & 0.02 & 0.04 & 0.30 & $0.06(0.08)$ \\
\hline $\mathrm{Hg}$ & $1(9 \%)$ & $<0.10$ & NA & 1.67 & NA \\
\hline TI & $11(100 \%)$ & NA & NA & NA & NA \\
\hline $\mathrm{Pb}$ & 0 & 0.23 & 0.54 & 3.28 & $0.76(0.88)$ \\
\hline \multicolumn{6}{|c|}{$2017(n=5)$} \\
\hline V & 0 & 0.06 & 0.07 & 0.18 & $0.09(0.05)$ \\
\hline $\mathrm{Cu}$ & 0 & 2.50 & 2.87 & 3.26 & $2.88(0.33)$ \\
\hline As & 0 & 0.04 & NA & 0.07 & NA \\
\hline $\mathrm{Cd}$ & 0 & 0.02 & 0.03 & 0.04 & $0.03(0.01)$ \\
\hline $\mathrm{Hg}$ & 0 & 0.84 & NA & 2.15 & NA \\
\hline $\mathrm{Tl}$ & $5(100 \%)$ & NA & NA & NA & NA \\
\hline $\mathrm{Pb}$ & 0 & 0.12 & 0.15 & 0.17 & $0.15(0.02)$ \\
\hline \multicolumn{6}{|c|}{ Masked Booby (Sula dactylatra) - adults } \\
\hline \multicolumn{6}{|c|}{$2016(n=16)$} \\
\hline $\mathrm{V}$ & 0 & 0.01 & 0.04 & 0.07 & $0.04(0.01)$ \\
\hline $\mathrm{Cu}$ & 0 & 2.35 & 2.77 & 5.52 & 3.08 \\
\hline As & $4(2$ & $<0.03$ & NA & 0.13 & NA \\
\hline $\mathrm{Cd}$ & 0 & 0.01 & 0.03 & 0.13 & $0.03(0.03)$ \\
\hline $\mathrm{Hg}$ & 0 & 1.69 & 2.02 & 2.83 & $2.18(0.38)$ \\
\hline $\mathrm{Tl}$ & 16( & NA & NA & NA & NA \\
\hline $\mathrm{Pb}$ & 0 & 0.32 & 0.54 & 5.04 & 0.85 (1.14) \\
\hline \multicolumn{6}{|c|}{$2017(n=4)$} \\
\hline V & 0 & 0.30 & 0.05 & 0.07 & $0.05(0.02)$ \\
\hline $\mathrm{Cu}$ & 0 & 2.24 & 2.50 & 3.03 & $2.57(0.34)$ \\
\hline As & $1(2$ & $<0.03$ & NA & 0.10 & NA \\
\hline $\mathrm{Cd}$ & 0 & 0.02 & 0.03 & 0.09 & $0.04(0.03)$ \\
\hline $\mathrm{Hg}$ & 0 & 1.58 & 1.84 & 2.66 & $1.98(0.47)$ \\
\hline $\mathrm{TI}$ & $4(100 \%)$ & NA & NA & NA & NA \\
\hline $\mathrm{Pb}$ & 0 & 0.15 & 0.68 & 1.74 & $0.81(0.73)$ \\
\hline \multicolumn{6}{|c|}{ Lesser Frigatebird (Fregata ariel) - juveniles } \\
\hline \multicolumn{6}{|c|}{$2016(n=14)$} \\
\hline $\mathrm{V}$ & 0 & 0.01 & 0.02 & 0.04 & $0.02(0.01)$ \\
\hline $\mathrm{Cu}$ & 0 & 1.09 & 1.50 & 2.17 & $1.50(0.27)$ \\
\hline As & $8(57 \%)$ & $<0.03$ & NA & 0.06 & NA \\
\hline $\mathrm{Cd}$ & 0 & 0.01 & 0.03 & 0.07 & $0.03(0.01)$ \\
\hline $\mathrm{Hg}$ & 0 & 0.14 & 0.27 & 0.37 & NA \\
\hline $\mathrm{Tl}$ & 14 & NA & NA & NA & NA \\
\hline $\mathrm{Pb}$ & 0 & 0.23 & 0.56 & 1.48 & $0.66(0.38)$ \\
\hline \multicolumn{6}{|c|}{$2017(n=9)$} \\
\hline $\mathrm{V}$ & 0 & 0.02 & 0.03 & 0.18 & $0.05(0.05)$ \\
\hline $\mathrm{Cu}$ & 0 & 1.15 & 1.36 & 2.27 & $1.45(0.34)$ \\
\hline As & $8(\varepsilon$ & $<0.03$ & NA & 0.05 & NA \\
\hline $\mathrm{Cd}$ & 0 & 0.02 & 0.04 & 0.10 & $0.06(0.03)$ \\
\hline
\end{tabular}




\begin{tabular}{llllll}
\hline $\mathrm{Hg}$ & $6(67 \%)$ & $<0.10$ & $\mathrm{NA}$ & 0.39 & $\mathrm{NA}$ \\
$\mathrm{Tl}$ & $9(100 \%)$ & $\mathrm{NA}$ & $\mathrm{NA}$ & $\mathrm{NA}$ & $\mathrm{NA}$ \\
$\mathrm{Pb}$ & 0 & 0.15 & 0.33 & 0.60 & $0.33(0.14)$ \\
\hline
\end{tabular}


Table 3

Summary of linear models testing the effects of species and year on feather trace element concentrations.

\begin{tabular}{llllll}
\hline Trace element & Factor & $\mathbf{F}^{\mathbf{1}}$ & $\mathbf{p}$-value & Post-hoc test & Log-transformed \\
\hline $\mathrm{V}$ & Species & 15.18 & $<0.001$ & $\mathrm{BB}>\mathrm{MB}>\mathrm{LF}$ & $\mathrm{Y}$ \\
& Year & 12.84 & $<0.001$ & $2017>2016$ & $\mathrm{Y}$ \\
$\mathrm{Cu}$ & Species $\times$ Year & 0.64 & 0.53 & $\mathrm{NA}$ & $\mathrm{Y}$ \\
& Species & 79.65 & $<0.001$ & $\mathrm{MB}=\mathrm{BB}>\mathrm{LF}$ & $\mathrm{Y}$ \\
$\mathrm{As}$ & Year & 0.92 & 0.34 & $\mathrm{NA}$ & $\mathrm{Y}$ \\
& Species $\times$ Year & 0.61 & 0.55 & $\mathrm{NA}$ & $\mathrm{Y}$ \\
& Species & 14.11 & $<0.001$ & $\mathrm{BB}=\mathrm{MB}>\mathrm{LF}$ & $\mathrm{N}$ \\
$\mathrm{Cd}$ & Year & 0.07 & 0.80 & $\mathrm{NA}$ & $\mathrm{N}$ \\
& Species $\times$ Year & 0.80 & 0.46 & $\mathrm{NA}$ & $\mathrm{N}$ \\
$\mathrm{Hg}$ & Species & 1.17 & 0.32 & $\mathrm{NA}$ & $\mathrm{Y}$ \\
& Year & 1.61 & 0.21 & $\mathrm{NA}$ & $\mathrm{Y}$ \\
& Species $\times$ Year & 1.43 & 0.25 & $\mathrm{NA}$ & $\mathrm{Y}$ \\
$\mathrm{Pb}$ & Species & 149.64 & $<0.001$ & $\mathrm{BB}=\mathrm{MB}>\mathrm{LF}$ & $\mathrm{N}$ \\
& Year & 0.23 & 0.63 & $\mathrm{NA}$ & $\mathrm{N}$ \\
& Species $\times$ Year & 4.20 & 0.020 & $\mathrm{NA}$ & $\mathrm{N}$ \\
& Species & 0.41 & 0.67 & $\mathrm{NA}$ & $\mathrm{Y}$ \\
& Year & 0.01 & 0.99 & $\mathrm{NA}$ & $\mathrm{Y}$ \\
& Species $\times$ Year & 2.53 & 0.09 & $\mathrm{NA}$ & $\mathrm{Y}$ \\
\hline
\end{tabular}

${ }^{1}$ Degrees of freedom are 2 \& 53 for "Species" and "Species $\times$ Year", and 1, 53 for "Year" 